\title{
E-Commerce Adoption in China's Service SMEs: A Study From Web Usability Perspective
}

\author{
Mingxuan Wu \\ Central Queensland University, Australia \\ Li Zhang \\ Xi' an Institute of Post and Telecommunications, China \\ Qiudan Xing \\ Shannxi Normal University, China \\ Li Dai \\ ZJCAN Zhenjiang, China \\ Hongmei Du \\ Changzhou Institute of Engineering Technology, China
}

\begin{abstract}
Although China's economy continues to grow rapidly over the last decade, some researchers have been aware that China has had to develop its service sector if China wants to sustain this growth. However, researches on the electronic commerce (e-commerce) adoption in China's service industries are still lacking and are limited so far. In literature review, few works discuss e-commerce adoption by measuring web site usability / web usability.

This paper reviews the research on China's small and medium enterprises (SMEs), and highlights the challenges for developing and adopting e-commerce in China's service SMEs. This research surveyed 494 of China's service SME websites, and found that (1) most of China's service SMEs are still at the early stage of adopting e-commerce; (2) there is an obvious e-commerce divide between Eastern China and Western China; (3) there is an existing positive relation between GDP per person and e-commerce adoption. This paper suggests that there is a need to select more sampling cities and make further research for justifying the above findings. Finally, this research concludes that web usability is the core of e-commerce adoption, and recommends the promotion of web usability as an effective strategy in further strategic development for China's service SMEs adopting e-commerce. This research believes that China's service sector adopting e-commerce might promote them up to the global level and stay competitive, which might further benefit the growth of China's economy immensely.
\end{abstract}

\section{Keywords}

Copyright (C) 2007 Victoria University. This document has been published as part of the Journal of Business Systems, Governance and Ethics in both online and print formats. Educational and non-profit institutions are granted a nonexclusive licence to utilise this document in whole or in part for personal or classroom use without fee, provided that correct attribution and citation are made and this copyright statement is reproduced. Any other usage is prohibited without the express permission of the
Contact links, e-commerce adoption, GDP, service industry, SMEs, web usability.

\section{Introduction}

As key contributors to the economic growth and employment in the global economy (DFAIT-MAECI 2004), the majority of 
small and medium enterprises (SMEs) have realised that electronic commerce (e-commerce) can fulfil their expectations (NUA 2002). The first reason is that today more than ever before, a small enterprise can use new technologies to respond quickly to change consumer patterns, customize goods and services to meet local demand, manage supply processes and inventories, and monitor production costs and quality control (Bologna 2000). Payne (2003) believes that SMEs would be in a very good position to adapt to new technology, which may be adapted faster in SMEs than larger companies who can be slowed by bureaucracy and stricter staffing hierarchies. The following is that the potential benefits of ecommerce to "level the playing field" will allow SMEs to compete better (Daniel \& Myers 2000), which gives SMEs a better chance to compete in their markets (Payne 2003). The last reason is that ecommerce can support SMEs to establish a commercial presence in foreign markets, entry and exit barriers in foreign markets may be barriers to their effective participation (DFAIT-MAECI 2004).

However, in review of e-commerce researches in SMEs, only a small number of studies focused on the adoption and use of e-commerce in SMEs (Grandon \& Pearson 2004, cited in Al-Qirim 2006, p.19). The results seemed to be disappointing and bring further gloom to the e-commerce adoption phenomenon in SMEs (Al-Qirim 2006, p.19). Therefore, many researchers warn that SMEs are being laggards in adopting or in using e-commerce more strategically in business (Abell \& Lim 1996; Abell \& Black, 1997; Adam \& Deans, 2000; Deloitte, 2000; Grandon \& Pearson, 2004; MOED, 2000a, 2000b; Poon, 2000; Poon \& Swatman, 1995, 1997, 1998, 1999a, 1999b; PWHC, 1999; Teo, Tan \& Buk, 1998, cited in Al-Qirim 2006, p.19).

Kristian Steenstrup, the research director at Gartner said "E-business will change Asia more than it changes the U.S." (Rao 2001). Schneider (2007, p.11) supports that the second wave is characterised by its international scope with sellers doing business in many countries and in many languages while the first wave of e-commerce was predominantly a U.S. phenomenon. Therefore, there is an urgent need for understanding SMEs adopting e-commerce in Asian countries, especially in China as the largest country in the world.

A few works have been published, such as Guo \& Chen (2005, p.55) find that some smaller China's companies adopt the Internet earlier than their larger counterparts. However, researches on e-commerce adoption in China's SMEs adopting are still lacking and are limited so far, especially in service SMEs. This paper focuses on e-commerce adoption in China's service SMEs from web site usability / web usability perspective.

\section{Research Background}

Although China's economy continues to grow rapidly over the last decade, some researchers have been aware that China has had to develop its service sector if China wants to sustain this growth. According to Spohrer (2005), there are some reasons why service sector is important. First, the economies of most developed countries are dominated by services ( $70 \%$ of the labor, GDP, etc.). Second, even traditional manufacturing companies like GE (70\% of services revenue) and IBM (50\% of services revenue) need to add high value services to grow their businesses. Third, research indicates that improving productivity - one type of service innovation - often requires technical-business, social-business, and social-demand innovations combined. One more reason is that service industries will be more active in the global marketplace in order to maintain their job and wealth-creation capability in an increasing integrated world (DFAIT-MAECI 2004). However, China's service sector has to face several challenges in adopting e-commerce.

\section{Classification of Service Industry}

China has a different classification of its service sector compared with advanced countries, such as Australia. According to the Australian Bureau of Statistics (ABS 2004), the service industries are divided into the 12 sections including wholesale trade, retail trade, accommodation/cafes/restaurants, transport/storage, communication services, finance/insurance services, property/business services, 
government administration/defence, education, health/community services, cultural/recreational services, and personal/ other services.

This research adopts the classification of the Australian Bureau of Statistics to conduct its analysis, and focuses on 10 different sectors in service industry excluding government administration/defence, and education. This would enhance the quality of communication with other researches.

\section{Definitions of SMEs}

There is no single agreed definition of an SME (APEC 2006, p.63). A variety of definitions are applied among Organization for Economic Cooperation and Development (OECD) countries, and employee numbers are not the sole defining criterion, which are generally considered to be non-subsidiary, independent firms which employ fewer than a given number of employees (APEC 2006, p.63). Daniel \& Myers (2000) believes that a widely accepted definition of SMEs is companies with less than 250 employees. IDC (2004) covers SMEs with 1-499 employees, segmented into 1-4, 5-9, 10-19, 20-49, 5099, 100-199, 200-499. In 2003, China announced a standard for SMEs. However, it just covers few industries (see Table 1) as follows:

Table 1: Definitions of SMEs in China

$\begin{array}{llll}\text { Industries } & \text { Business Size } & \text { No. of Employees } & \begin{array}{l}\text { Business Sales } \\ \text { (Million CNY) }\end{array} \\ \text { Manufacturing } & \text { Medium } & 300-2000 & 30-300 \\ & \text { Small } & <300 & <30 \\ \text { Construction } & \text { Medium } & 600-3000 & 30-300 \\ & \text { Small } & <600 & <30 \\ \text { wholesale trade } & \text { Medium } & 100-200 & 30-300 \\ & \text { Small } & <100 & <30 \\ \text { Retail trade } & \text { Medium } & 100-500 & 10-150 \\ & \text { Small } & <100 & <10 \\ \text { Accommodation/restaurant } & \text { Medium } & 400-800 & 30-150 \\ & \text { Small } & <400 & <30 \\ \text { Transport } & \text { Medium } & 500-3000 & 30-300 \\ & \text { Small } & <500 & <30 \\ \text { Post communication service } & \text { Medium } & 400-1000 & 30-300 \\ & \text { Small } & <400 & <30\end{array}$

(Source: Xinhuanet 2003)

\section{Challenges for E-commerce adoption in China's Service SMEs}

Currently, there are at least three challenges for e-commerce adoption in China's service SMEs as follows:

China's service sector is still the least developed compared with advanced countries

In 2005, China has 3.65 million SMEs and 28 million individual businesses, which accounts for $99.6 \%$ of all industries (China Daily 2005), and up from 98.99\% in 2003 (Luo \& Guo 2005). However, China's service sector is only 40.3\% share of China's GDP in 2005 (Stats 2006). China's service sector is still one of the least developed in the world (Chen 2005, p.13) compared with a service sector share of $71.6 \%$ in Australia (ABS 2004) and 79.4\% in the US (Chen 2005, p.13).

Thus, some researchers are aware that China as "the world's factory" is already being challenged, and must develop its service sector (Chen 2005, p.13), because: (1) being the 'world's factory' has taken its toll on China's environment; (2) China has faced more and more tough hurdles to further expanding its world market share in manufactured goods; (3) manufacturing can no longer create new jobs. 


\section{Internet penetration is the last second among the top ten languages used on the web}

On 30 June 2007, the Chinese has been the top second Internet Language used on the web (Internet World Stat 2007) (see Figure 1). In the meantime, the number of computers connected to Internet continues to grow up in China, which is 59.4 million in Dec 2006, and up from 8.92 million in 2000, 12.54 million in 2001, 20.83 million in 2002, 30.89 million in 2003, 41.60 million in 2004, and 49.50 million in 2005 (CNNIC 2007, p.12) (see Figure 2).

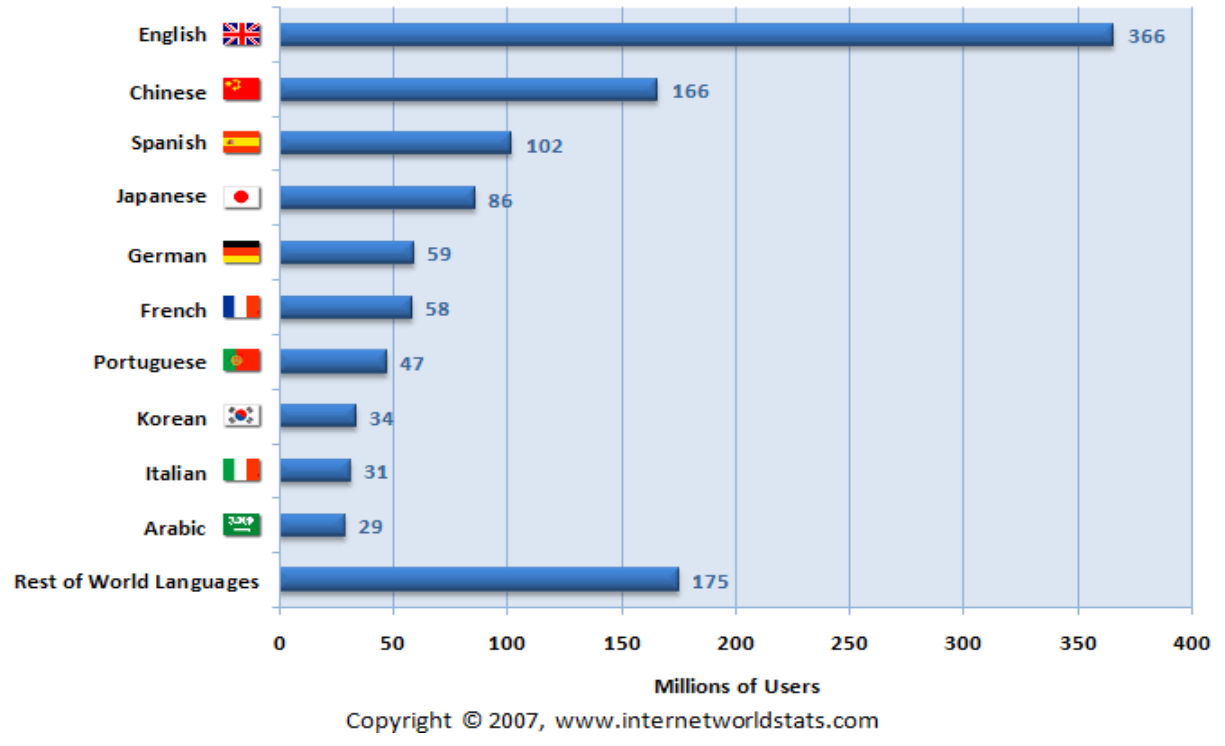

Figure 1: Top Ten Internet Languages (Source: Internet World Stat 2007)

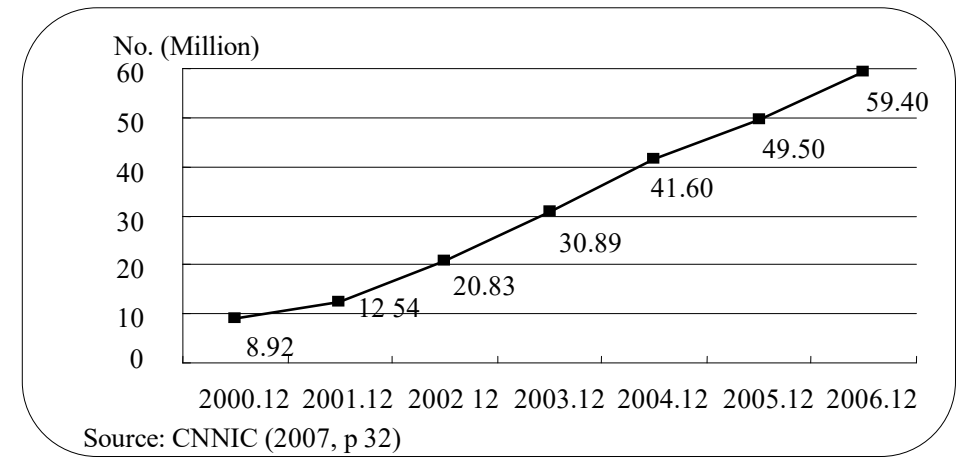

Figure 2: The Number of Computers Connected to Internet in China

However, Internet penetration by language in China is only $12.3 \%$, which is the last second among the top ten languages used on the web, and is just more than Arabic (see Table 2). 
Table 2: Top Ten Languages Used on the Web (Number of Internet Users by Language)

\begin{tabular}{|c|c|c|c|c|c|}
\hline $\begin{array}{r}\text { TOP TEN } \\
\text { LANGUAGES } \\
\text { IN THE INTERNET }\end{array}$ & $\begin{array}{r}\text { \% of all } \\
\text { Internet } \\
\text { Users }\end{array}$ & $\begin{array}{r}\text { Internet Users } \\
\text { by Language }\end{array}$ & $\begin{array}{r}\text { Internet } \\
\text { Penetration } \\
\text { by Language }\end{array}$ & $\begin{array}{r}\text { Internet } \\
\text { Growth } \\
\text { for Language } \\
(2000-2007)\end{array}$ & $\begin{array}{r}2007 \text { Estimate } \\
\text { World Population } \\
\text { for the Language }\end{array}$ \\
\hline English & $31.7 \%$ & $365,893,996$ & $17.9 \%$ & $157.7 \%$ & $2,042,963,129$ \\
\hline Chinese & $31.7 \%$ & $166,001,513$ & $12.3 \%$ & $413.9 \%$ & $1,351,737,925$ \\
\hline$\underline{\text { Spanish }}$ & $8.8 \%$ & $101,539,204$ & $22.9 \%$ & $311.4 \%$ & $442,525,601$ \\
\hline$\underline{\text { Japanese }}$ & $7.5 \%$ & $86,300,000$ & $67.1 \%$ & $83.3 \%$ & $128,646,345$ \\
\hline$\underline{\text { German }}$ & $5.1 \%$ & $58,981,592$ & $61.1 \%$ & $112.9 \%$ & $96,488,326$ \\
\hline French & $5.1 \%$ & $58,456,702$ & $15.1 \%$ & $379.2 \%$ & $387,820,873$ \\
\hline$\underline{\text { Portuguese }}$ & $4.1 \%$ & $47,326,760$ & $20.2 \%$ & $524.7 \%$ & $234,099,347$ \\
\hline Korean & $3.0 \%$ & $34,120,000$ & $45.6 \%$ & $79.2 \%$ & $74,811,368$ \\
\hline$\underline{\text { Italian }}$ & $2.7 \%$ & $31,481,928$ & $52.9 \%$ & $138.5 \%$ & $59,546,696$ \\
\hline$\underline{\text { Arabic }}$ & $2.5 \%$ & $28,782,300$ & $8.5 \%$ & $940.5 \%$ & $340,548,157$ \\
\hline $\begin{array}{r}\text { TOP TEN } \\
\text { LANGUAGES } \\
\end{array}$ & $84.8 \%$ & $978,883,995$ & $19.0 \%$ & $198.0 \%$ & $5,159,187,766$ \\
\hline $\begin{array}{r}\text { Rest of World } \\
\text { Languages }\end{array}$ & $15.2 \%$ & $175,474,783$ & $12.4 \%$ & $440.3 \%$ & $1,415,478,651$ \\
\hline WORLD TOTAL & $100.0 \%$ & $1,154,358,778$ & $17.6 \%$ & $219.8 \%$ & $6,574,666,417$ \\
\hline
\end{tabular}

(*) NOTES: (1) Internet Top Ten Languages Usage Stats were updated for June 30, 2007. (2) Internet Penetration is the ratio between the sum of Internet users speaking a language and the total population estimate that speaks that specific language. (3) The most recent Internet usage information comes from data published by Nielsen//NetRatings, International Telecommunications Union, Computer Industry Almanac, and other reliable sources. (4) World population information comes from the world gazetteer web site. (5) For definitions and navigation help, see the Site Surfing Guide. (6) Stats may be cited, stating the source and establishing an active link back to Internet World Stats. Copyright (C) 2007, Miniwatts Marketing Group. All rights reserved.

(Source: Internet World Stat 2007)

\section{Theoretical Framework and Research Methodology}

A crucial success factor in e-commerce is the development of an appealing, effective, and efficient web site (Belanger 2006, p.i). This is due to web site becoming a global platform used by individuals, organisations, and governments worldwide (Belanger 2006, p.i), and a powerful medium for worldwide information dissemination and e-commerce (Singh, Dalal, \& Spears 2005, p.288), and an important part of a successful e-commerce operation to meet the needs of potential customers (Schneider 2007, p.151). Agarwal \& Venkatesh (2002, p.169) highlight to measure the quality of its web presence through a key concept that emerges from human-computer interaction (HCI) research-that of usability. Therefore, web usability is the core of e-commerce development and adoption. In literature review, little works discuss e-commerce adoption by measuring web usability.

\section{Studying E-Commerce Adoption by Measuring Web Usability}

The notion of usability has been defined in a variety of ways by scholars (Nielsen 1994, Karat 1997; Gray \& Salzman 1998; Lecerof \& Paterno 1998; Lecerof \& Paterno 1998; and Nielsen 2000, cited in Agarwal \& Venkatesh 2002, p.169). Spool (1998 cited in Sandvig \& Bajwa 2004, p.15) and Nielsen (2001 cited in Sandvig \& Bajwa 2004, p.15) note that web usability is typical measured by observing web users as they attempt to complete a given set of tasks. Sandvig \& Bajwa $(2004$, p.15) define web usability as the study of how web users interact with web pages and site navigation. Schneider (2007, 
p.146) believes that the study of web usability can understand how companies can improve their web presences by making their sites accessible to more people and easier to use, and by making sure that their sites encourage visitors to trust and even develop feelings of loyalty toward the organisation behind the web sites. Currently, more and more companies are realising the importance of web usability testing, and are doing some testing (Schneider 2007, p.150).

In fact, the emergence of usability testing and laboratories has been an indicator of the profound shift in attention to user needs since the early 1980s (Shneiderman 1998, p. 127, cited in Sandvig \& Bajwa 2004, p.15). Such as Agarwal \& Venkatesh (2002) develop an evaluation procedure for website usability including content, ease of use, promotion, made-for-the-medium, and emotion. As two pioneers of usability testing, Dr. Ben Shneiderman founded the University of Maryland HCI Lab, and Dr. Jakob Nielsen established Alerbox web to analyse the current issues in web usability (Schneider 2007, p.150). These tests are often conducted on new or redesigned web sites to evaluate how well a representative sample of the web sites target population can navigate the site (Sandvig \& Bajwa 2004, p.15).

According to Goldsborough (2005, p.40), if a business uses web site to promote or sell its products or services, the life of this business may depend on whether its web site shows up in the first screen or two when people conduct web searches through Google and other search sites. Jansen (2007, P.24) further highlights that sponsored search is an effective method for providing relevant information to web searchers for the e-commerce area.

However, the web site searched by search engines or linked by other web sites is just the initial step for a business adopting e-commerce. Both Goldsborough and Jansen ignore another two critical factors. The first factor is whether web site is effective. Web site is a crucial determinant of whether visitors are likely to return to the site (Klein 1998, cited in Agarwal \& Venkatesh 2002, p.168). If it is ineffective, web site might not work out properly. It should be difficult for potential customers to find out business's products and services well. Nielsen (2000, p.11, cited in Agarwal \& Venkatesh 2002, p.168) highlights that users experience usability first and pay later on the web. Therefore, it is impossible that web visitors get failed or bad experiences and may come back to these web sites again because they have many options on the web. Another factor is whether contact e-mail address or link provided on the web site is valid. Generally, e-commerce web sites provide the different channels for users easily to contact sales representatives or businesses. Compared with the traditional ways such as post mailing address, telephone number, and fax number, contact e-mail address or link is an effective e-channel provided on the web site which visitors are easy to be made contact with. Song \& Zahedi (2005, p.1224) indicate that contact function in e-commerce website design is one of the significant roles of elements related to service. For an example, few firms had e-mail address links on their web sites but they often understaffed the department responsible for answering visitors' e-mail messages so that many site visitors sent e-mail messages that were never answered (Schneider 2007, p.146). If contact link is invalid, therefore, businesses might not be made contact with by visitors easily. For these reasons, this research just address the percentage of usable websites to measure the terms of web usability, which focuses on two critical factors - the effective web sites and valid contact links.

\section{Research Methodology}

This research adopts the random sampling method to select the samples. The first step is to define the different service sectors. The second step is to select the cities. The third step is to use a random selection procedure to select samples from China's Yellowpage (http://www.yellowpage.com.cn) online. However, most of China' service SMEs do not establish web sites. On the other hand, most of businesses do not provide their web site links in China's Yellowpage web site even if they have. Therefore, search engine is used to search business web sites according to the business name selected by the third step. This research chooses the Chinese Baidu (www.baidu.com) as the main search engine.

The data was collected from 13 November 2006 to 18 December 2006 during 5 weeks period. All data are recorded in order to analyse and monitor any changes. First is to survey whether all web sites still 
work properly on 18 December while they all work well on 13 November. Second is to test whether all contact links listed in the effective web sites are valid.

\section{Data Analysis and Findings}

\section{Data Analysis}

Totally, 494 service SMEs were selected from four sampling cities including Xi'an (162) in Western China, Taiyuan (152) in Middle China, Zhenjiang (123) in Eastern China, and Changzhou (57) in Eastern China (see Figure 4)

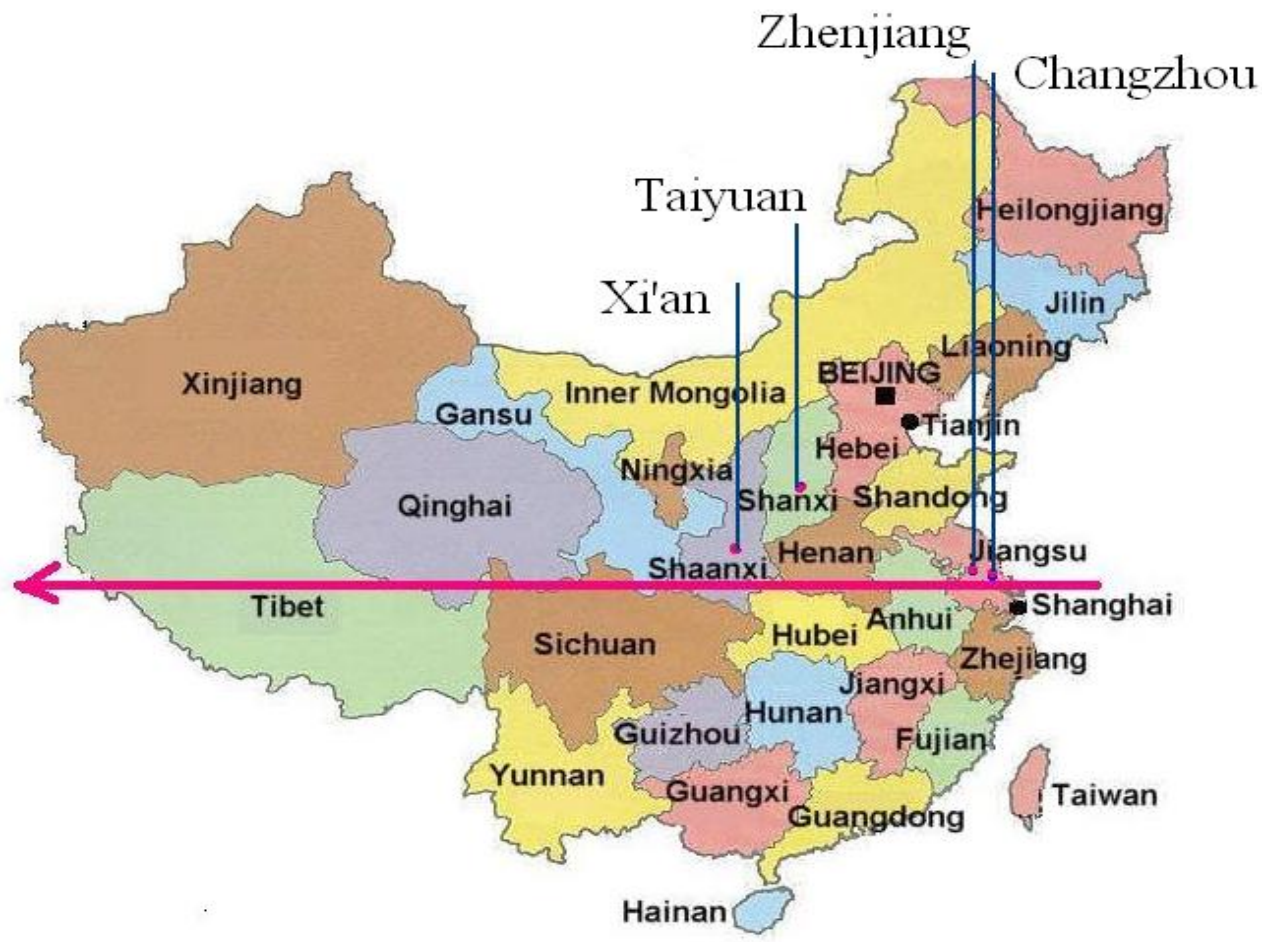

Figure 4: The Location of Sampling Cities in China's Map

Table 3 shows GDP and GDP per person in sampling cities as follows:

- $\quad$ GDP (130.22 Billion CNY), GDP per Person (37,174 CNY) in Changzhou - a larger city in Eastern China.

- $\quad$ GDP (90.5 Billion CNY), GDP per Person (33,870 CNY) in Zhengiiang - a medium city in Eastern China.

- $\quad$ GDP (89.549 Billion CNY), GDP per Person (26,175 CNY) in Taiyuan - a larger city in Middle China.

- $\quad$ GDP (127.014 Billion CNY), GDP per Person (15,925 CNY) in Xi'an - a larger city in Western China.

Table 3: GDP and GDP per Person in Sampling Cities

\begin{tabular}{|lllrr|}
\hline \multicolumn{1}{|c}{ City } & Location & \multicolumn{1}{c}{ Size } & \multicolumn{1}{c|}{ GDP } \\
(Billion CNY) & $\begin{array}{r}\text { GDP Per Person } \\
\text { (CNY) }\end{array}$ \\
\hline Changzhou & Eastern & Larger & 130.22 & 37,174 \\
Zhenjiang & Eastern & Medium & 90.5 & 33,870 \\
Taiyuan & Central & Larger & 89.549 & 26,175 \\
Xi'an & Western & Larger & 127.014 & 15,925 \\
\hline
\end{tabular}


Notes: (1) GDP, GDP per Person of the city of Changzhou are provided by Loone (2006).

(2) GDP, GDP per Person of the city of Zhenjiang are provided by Zhenjiang Government (2006).

(3) GDP, GDP per Person of the city of Taiyuan are provided by Taiyuan Statistics (2006).

(4) GDP, GDP per Person of the city of Xi'an are provided by Xi' an Information Centre (2006). 
Table 4 shows the effective web sites in sampling cities as follows:

- $\quad 85.19 \%$ (138 out of 162) of web sites in Xi' an are effective, and 14.81\% (24 out of 162) are dead. Here, the dead web sites include "this domain name has expired", "web changed", "website shut down", "invalid hostname", "web site does not work", "domain name changed", "server not found", "directory listing denied", and "no web sites configured at this address".

- $\quad 88.16 \%$ (134 out of 152) of web sites in Taiyuan are effective, and 11.84\% (18 out 152) are dead.

- $\quad 90.24 \%$ (111 out 123) of web sites in Zhenjiang are effective, and 9.76\% (12 out of 123) are dead.

- $\quad 100 \%$ of web sites in Changzhou are effective and work out. None is dead.

- Total $89.07 \%$ (440 out of 494) of web sites are effective, and 10.93\% (54 out of 494) are dead.

Table 4: The Effective Web Sites in Sampling Cities

\begin{tabular}{|lrrrrr|}
\hline \multirow{1}{*}{ City } & \multicolumn{2}{c}{ Effective Websites } & \multicolumn{2}{c|}{ Dead Websites } & \multicolumn{1}{c|}{ Sum } \\
\cline { 2 - 6 } & no. & $\%$ & no. & \multicolumn{1}{c}{$\%$} & no. \\
\hline Xi'an & 138 & $85.19 \%$ & 24 & $14.81 \%$ & 162 \\
Taiyuan & 134 & $88.16 \%$ & 18 & $11.84 \%$ & 152 \\
Zhenjiang & 11 & $90.24 \%$ & 12 & $9.76 \%$ & 123 \\
Changzhou & 57 & $100.00 \%$ & 0 & $0.00 \%$ & 57 \\
\hline Total & 440 & $89.07 \%$ & 54 & $10.93 \%$ & 494 \\
\hline
\end{tabular}

Table 5 shows web sites with valid contact links and web sites with invalid contact links among 440 effective web sites in four cities as follows:

- $\quad 83.33 \%$ (115 out of 138$)$ of web sites with contact links among 138 effective web sites in Xi'an are valid, $16.67 \%$ (23 out of 138 ) are invalid.

- $\quad 84.33 \%$ (113 out of 134 ) in Taiyuan are valid, and $15.67 \%$ (21 out of 134 ) are invalid.

- $\quad 81.08 \%$ (90 out 111 ) in Zhenjiang are valid, and 18.92\% (21 out of 111) are invalid.

- $\quad 98.25 \%$ (56 out of 57) are valid in Changzhou, and only one (1.75\%, 1 out of 57 ) is invalid.

- Totally, $85.00 \%$ (374 out of 440 ) of contact links among 440 effective web sites are valid, and $15.00 \%$ (66 out of 440 ) are invalid.

Table 5: Valid Contact Links among the Effective Web Sites

\begin{tabular}{|c|c|c|c|c|c|}
\hline \multirow[t]{2}{*}{ City } & \multicolumn{2}{|c|}{ Valid Contact Links } & \multicolumn{2}{|c|}{ Invalid Contact Links } & \multirow{2}{*}{$\begin{array}{c}\text { Sum } \\
\text { no. }\end{array}$} \\
\hline & no. & $\%$ & no. & $\%$ & \\
\hline Xi'an & 115 & $83.33 \%$ & 23 & $16.67 \%$ & 138 \\
\hline Taiyuan & 113 & $84.33 \%$ & 21 & $15.67 \%$ & 134 \\
\hline Zhenjiang & 90 & $81.08 \%$ & 21 & $18.92 \%$ & 111 \\
\hline Changzhou & 56 & $98.25 \%$ & 1 & $1.75 \%$ & 57 \\
\hline Total & 374 & $85.00 \%$ & 66 & $15.00 \%$ & 440 \\
\hline
\end{tabular}

Here invalid links include "maildir over quota", "no mailbox here by that name", "server not found", "quota exceed", "mailbox full", "mailbox space not enough", "undelivered Mail Returned to Sender:temporary failure"," domain is over quota","user mailbox exceeds allowed size", "user is over quota"," mailbox currently unavailable", "invalid User", "unable to relay for", " recipient address rejected: unknow user", "couldn't find any host named XXXX.XXX.cn", "wasn't able to establish an SMTP connection".

Thus, table 6 shows the usable websites in sampling cities as follows:

- 162 service SMEs web sites were surveyed in Xi'an. They includes the usable websites $(70.99 \%$, 115 out of 162$)$, websites with invalid contact links $(4.20 \%, 23$ out of 162), and dead web sites $(14.81 \%, 24$ out of 162$)$.

- 152 service SMEs web sites were surveyed in Taiyuan. They includes the usable websites $(74.34 \%, 113$ out of 152$)$, web sites with invalid contact links $(13.83 \%, 21$ out of 152$)$, and dead web sites $(11.84 \%, 18$ out of 152$)$. 
- 123 service SMEs web sites were surveyed in Zhengjiang. They includes the usable websites (73.17\%, 90 out 123$)$, web sites with invalid contact links $(17.07 \%, 21$ out of 123$)$, and dead web sites $(9.76 \%, 12$ out of 123$)$.

- 57 service SMEs web sites were surveyed in Changzhou. They includes the usable websites ( $98.25 \%, 56$ out of 57$)$, web sites with invalid contact links $(0.75 \%, 1$ out of 57$)$, and none of dead web sites.

Table 6: The Usable Websites in Sampling Cities

\begin{tabular}{|lrrrrrrr|}
\hline \multirow{1}{*}{ City } & \multicolumn{2}{c}{ Usable Websites } & \multicolumn{2}{c}{ Websites with Invalid Links } & \multicolumn{2}{c|}{ Dead Websites } & Sum \\
\cline { 2 - 8 } & No. & \multicolumn{1}{c}{$\%$} & No. & \multicolumn{1}{c}{$\%$} & \multicolumn{1}{c}{ No. } & \multicolumn{1}{c}{$\%$} & No. \\
\hline Xi'an & 115 & $70.99 \%$ & 23 & $14.20 \%$ & 24 & $14.81 \%$ & 162 \\
Taiyuan & 113 & $74.34 \%$ & 21 & $13.82 \%$ & 18 & $11.84 \%$ & 152 \\
Zhenjiang & 90 & $73.17 \%$ & 21 & $17.07 \%$ & 12 & $9.76 \%$ & 123 \\
Changzhou & 56 & $98.25 \%$ & 1 & $1.75 \%$ & 0 & $0.00 \%$ & 57 \\
\hline Total & 374 & $75.71 \%$ & 66 & $13.36 \%$ & 54 & $10.93 \%$ & 494 \\
\hline
\end{tabular}

Therefore, the terms of web usability provided in this research is $70.99 \%$ (Xi'an), $74.34 \%$ (Taiyuan), $73.17 \%$ (Zhenjiang), and 98.25\% (Changzhou).

\section{Findings}

Finding 1: Most of China's service SMEs are still at the early stage of adopting e-commerce

This research surveys all IT service providers (ISPs) in Zhengjiang, one of sampling cities, listed in China's Yellowpage online. However, only 20.18\% (22 out of 109) of ISPs have established their own web sites including effected web sites $(8.35 \%, 20$ out of 109$)$, web site with only one web page $(0.92 \%$, 1 out of 109), and dead web site $(0.92 \%, 1$ out of 109) (see Table 7).

Table 7: ISPs' Web Sites in Zhenjiang- One of Sampling Cities

\begin{tabular}{|c|c|c|c|c|c|c|c|c|c|c|}
\hline \multicolumn{8}{|c|}{ Web Sites } & \multicolumn{2}{|c|}{ Non-Web Sites } & \multirow[t]{2}{*}{ Total } \\
\hline & ctive & & Page & & ead & & $\mathrm{um}$ & & & \\
\hline no & $\%$ & no & $\%$ & no & $\%$ & no & $\%$ & no & $\%$ & no \\
\hline 20 & $18.35 \%$ & 1 & $0.92 \%$ & 1 & $0.92 \%$ & 22 & $20.18 \%$ & 87 & $79.82 \%$ & 109 \\
\hline
\end{tabular}

Totally, $79.82 \%$ (87 out of 109) of ISPs do not have any web sites or even web pages. Therefore, most of ISPs have not established web sites to support their business activities and provided their services through web sites yet. Clearly, other service sectors might be less than ISPs in this term. A China's research also supports this finding that the number of China's businesses connected to the Internet is less than $1.5 \%$ of all of businesses (Yu 2005).

Owens (2006, p.24) divides the development of e-commerce in the last decade into three generations, which includes that the first generation efforts to conduct e-commerce preceded the Internet, and in the second generation most businesses progressed in e-commerce to where they could conduct sales transactions electronically, and the third generation of e-commerce that the integration of information technology infrastructure to create an e-business.

According to Owens's standards, therefore, most of China's services SMEs are still at the early stages of adopting e-commerce so far. This finding is similar with Peet, Brindley, \& Ritchie' research in Europe (Peet, Brindley, \& Ritchie 2002, cited in Al-Qirim 2006, p.19) that SMEs' web sites lack interactivity and are limited to text-based content, and also similar with Al-Qirim's research in New Zealand that SMEs establish web sites primarily to advertise and to promote their business rather than to conduct e-commerce as such (Al-Qirim 2006, p.19). 


\section{Finding 2: There is an obvious e-commerce divide between Western China and Eastern China}

Simon (2004) emphasises that Internet adoption and gains in efficiency and productivity from the Internet have not yet been replicated in the developing world and has led to the coining of the term digital divide. Mandal (2004, p.1) highlights digital divide as the phenomena which is responsible for imbalanced growth of e-commerce among developed and developing countries.

However, this phenomenon also exists within China while this research focuses on the difference between Changzhou and Xi' an in terms of GDP and web usability. This research finds that there is an obvious e-commerce divide between Western China and Eastern China (see Table 7) as follows:.

- $\quad$ There is an only $2.52 \%$ difference in GDP between Changzhou (130.22 Billion CNY) and Xi'an. (127.014 Billion CNY)

- There is an obvious gap in the terms of web usability (38.40\%) between Changzhou (98.25\%) and Xi'an $(70.99 \%)$.

Also, the evidence from the latest Internet survey in China published on 23 Jan 2007 (CNNIC 2007, p.74) supports this finding that the adoption of Internet in Eastern China is obviously higher than its adoption in Western China. Generally, service SMEs adopting e-commerce in Eastern China is better than Western China.

Table 7: E-commerce Divide Between Eastern and Western China

\begin{tabular}{|lrr|}
\hline \multicolumn{1}{|c}{ City } & \multicolumn{1}{c}{$\begin{array}{c}\text { GDP } \\
\text { (Billion CNY) }\end{array}$} & $\begin{array}{c}\text { Web Usability } \\
\%\end{array}$ \\
\hline Changzhou & 130.22 & $98.25 \%$ \\
Xi'an & 127.014 & $70.99 \%$ \\
\hline Difference & $2.52 \%$ & $38.40 \%$ \\
\hline
\end{tabular}

Finding 3: There is a positive relation between GDP per person and e-commerce adoption.

Table 8 shows a positive relation between GDP per person and e-commerce adoption as follows.

- $\quad$ The GDP per person in Changzhou (37,174 CNY) is the highest one. Its web usability $(98.25 \%)$ is also the highest one.

- $\quad$ The GDP per person in Taiyuan $(26,175 \mathrm{CNY})$ and Zhenjiang $(33,870 \mathrm{CNY})$ are in the middle. Therefore, their web usability $(74.34 \%$ and $73.17 \%)$ are also in the middle.

- $\quad$ The GDP per person in Xi' an $(15,925$ CNY) is the lowest one. Its web usability (70.99\%) is also the lowest one.

Table 8: GDP per Person \& Web Usability

\begin{tabular}{|lrr|}
\hline City & $\begin{array}{c}\text { GDP Per Person } \\
\text { (CNY) }\end{array}$ & $\begin{array}{c}\text { Web Usability } \\
\%\end{array}$ \\
\hline Changzhou & 37,174 & $98.25 \%$ \\
Zhenjiang & 33,870 & $73.17 \%$ \\
Taiyuan & 26,175 & $74.34 \%$ \\
Xi'an & 15,925 & $70.99 \%$ \\
\hline
\end{tabular}

Clearly, there is a positive relation between GDP per person and web usability (see Figure 5): 


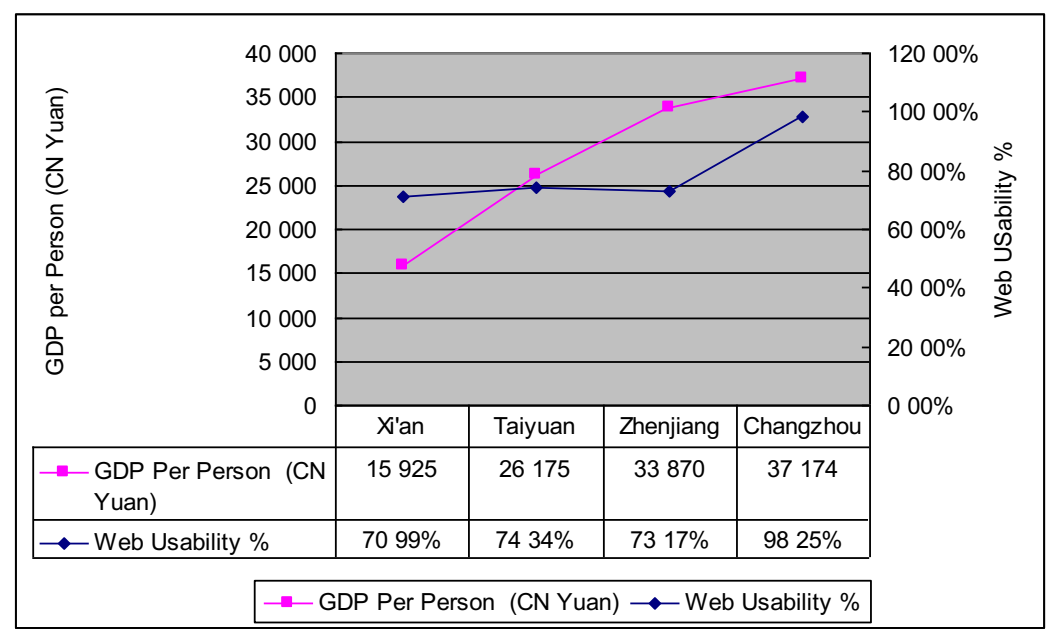

Figure 5: GDP per Person vs. Web Usability

\section{Limitation and Further Research}

The data presented in this paper were from a survey research for understanding the current situation of China's service SMEs adopting e-commerce. However, the questionnaires do not really be relevant to this work. Therefore, details about this survey and research questions do not be provided in this paper. Overall, this research finds that (1) most of China's service SMEs are still at the early stage of adopting e-commerce; (2) there is an obvious e-commerce divide between Eastern China and Western China; (3) there is an existing positive relation between GDP per person and e-commerce adoption.

On the other hand, there are at least other three limitations in this research as (1) the sample size of Changzhou- one of sampling cites is smaller compared with others; (2) the number of sample clusters are smaller (four cities), which is difficult to be conducted by a statistic analysis; (3) just addressing the percentage of usable websites as measurement criteria to evaluate the terms of web usability is too narrow.

In further research, therefore, there is a need to select more sampling cities for justifying the findings presented in this paper. One more thing is that more elaborated works involved in dynamic content need be done, such as in terms of broken URLs, broken pages, broken links, broken anchors, missing titles, missing attributes, old pages, slow pages, orphaned files, download times, and shutdown interval etc.

This paper concludes that web usability is the core of e-commerce adoption, and recommends that the promotion of web usability as an effective strategy in further strategic development for China's service SMEs adopting e-commerce. This research believes that China's service sector adopting e-commerce might promote them up to the global level and stay competitive, which might further benefit the growth of China's economy immensely.

\section{Endnote}

This paper is a continuing work updated and based on an early brief article, which has been presented at 2007 International Symposium on Information Systems \& Management (2007 ISM: the Management track of WiCOM2007) (IEEE 2007 ISM), July 25-28 2007, Shanghai, P.R.China.

\section{Acknowledgements}

Many thanks for two anonymous reviewers' valuable contributions and comments to the revision of this paper. 


\section{References}

ABS (2004). "Year Book 2003 Australian: Service Industries Overview”. viewed 28 Feb, 2006. http://www.abs.gov.au/ausstats/abs@.nsf/Previousproducts/598FB856F3D486B5CA256DEA0005 3A2E?opendocument.

Agarwal, R., \& Venkatesh, V. (2002), “Assessing a Firm's Web Presence: A heuristic evaluation procedure for the measure of Usability”, Information Systems Research, vol. 13, no.2, pp.168-188

Al-Qirim, N. (2006), "Personas of E-Commerce Adoption in Small Businesses in New Zealand", Journal of Electronic Commerce in Organizations, vol. 4, no.3, pp.17-45.

APEC (2006), "Removing Barriers to SME Access to International Markets", viewed [online] http://www.apec.org/apec/apec groups/working groups/small and medium enterprises.MedialibDo wnload.v1.html?url=/etc/medialib/apec media library/downloads/workinggroups/smewg/misc/2006. Par.0005.File.v1.1.

Belanger, F. (2006), "E-Commerce Web Development: Perspective from the Field”, Journal of Electronic Commerce in Organizations; , vol. 4,no.2.

Bologna (2000), 'ROUNDTABLE 3: Realising the Potential of Electronic Commerce for SMEs in the Global Economy', BOLOGNA 2000 SME Conference Business Symposium, Bologna, Italy, 13 June 2000. [online]. Available at URL: http://www.conferenzabologna.ipi.it/Eng /dopo la conferenza/documenti/RT3 en.pdf [Accessed 27 September 2004].

Chen Z.W. (2005), "A free Press Could Help China's Economy”, Financial Times, 20 Sep, p.13, UK

China Daily (2005). "Nation to Aid SMEs' Overseas Ventures". viewed 23 Jan,2006. http://www.china.org.cn/english/BAT/143081.htm .

CNNIC (2007). "The 19th Survey of China's Internet Status"." viewed 1 Feb 2007. http://www.cnnic.net.cn/uploadfiles/doc/2007/1/23/113530.doc

Daniel, E. \& Myers, A. (2000), 'Levelling the Playing Field: Electronic Commerce in Small and Medium Enterprises', viewed 8 Sep 2004, [online]. Available at URL: http://mn-isweb1.som.cranfield.ac.uk/publications/ISRC 2001 SME-Report.pdf.

DFAIT-MAECI (2004). "Canada and Trade in Services.” viewed 24 Sep, 2005. http://www.dfaitmaeci.gc.ca/tna-nac/TS/small-med-en.asp.

Goldsborough, R. (2005), "Get Your Site Noticed Without Spamming”, Black Issues in Higher Education, vol. 21,no.26, p.40.

Guo, X. H., \& Chen, G.Q. (2005), "Internet Diffusion In Chinese Companies”, Communications of the ACM, vol. 48,no.4, pp.54-58.

IDC (2004), 'Fact Sheet: Australia Small and Medium Business Markets', 26 March- last update, viewed 7 Sep 2004, [online]. Available at URL: http://www.idc.com.au/research /factsheets/it sme business.htm.

Internet World Stats (2007), "Internet World Users By Language”, viewed 25 July 2007, [online] http://www.internetworldstats.com/stats7.htm.

Javalgi, R. G., Wickramasinghe, N., Scherer, R.F. \& Sharma, S.K (2005), “An Assessment and Strategic Guidelines for Developing E-Commerce in the Asia-Pacific Region", International Journal of Management, vol. 22,no.4, pp.523-531.

Jansen, B. J. (2007), "The Comparative Effectiveness of Sponsored and Non-sponsored Links for Web E-commerce Queries", ACM Transactions on the Web, vol. 1,no.1, pp.1-25.

Loone (2006), "2005 Statistics Bulletin For The National Economic And Social Development in Changzhou", viewed 19 Dec 2006, [online] http://www.loone.cn /misc/200602/15/content 415329.htm .

Luo Z.W. \& Guo C.X. (2005). "The Strategy to Speed The Development of China's SMEs". viewed 16 Jan,2006. http://theory.people.com.cn/GB/49154/49155/3871074.html.

Mandal, P. (2004), "Inter-country Analysis of E-Business", Journal of Global Information Technology Management, vol. 7,no.2, pp.1-5

NUA, (2002), "The Age: Australian SMEs embrace ecommerce", 31 Jul 2002 - last update [online]. Available at URL: http://www.nua.com/surveys/?f=VS\&art id=905358226\&rel=true [Accessed 29 December, 2004]. 
Owens, J. D. (2006), "Electronic business: A business model can make the difference", Management Services, vol. 50,no.1, pp.24-28.

Payne, J. E.(2003), "E-Commerce Readiness for SMEs in Developing Countries: A Guide for Development Professionals,", 07 May 2003 - last update [online]. Available at URL: http://learnlink.aed.org/Publications/Concept Papers/ecommerce readiness.pdf [Accessed 28 September 2004].

Rao, M. (2001). "E-business will change Asia more than it changes the U.S." viewed 31 Jan,2006. http://www.indiainfoline.com/nevi/inwi/mm52.html.

Sandvig, J. C., \& Bajwa, D. (2004), "Information Seeking On University Web Sites: An Exploratory Study", The Journal of Computer Information Systems, vol. 45,no.1, pp.13-22.

Schneider, G. P. (2007). "Electronic Commerce", $7^{\text {th }}$ edn, Thomson, Canada.

Simon, S. J. (2004), "Critical Success Factors for Electronic Services: Challenges for Developing Countries", Journal of Global Information Technology Management, vol. 7,no.2, pp.31-53

Singh, S. N., Dalal, N., \& Spears, N. (2005), "Understanding Web home page perception”, European Journal of Information Systems, vol. 14, pp.288-302.

Song, J., \& Zahedi, F.M. (2005), "A Theoretical Approach to Web Design in E-Commerce: A Belief Reinforcement Model”, Management Science, vol. 51,no.8, pp.1219-1235.

Spohrer J.C., (2005), Service Sciences, Engineering, and Management (SSEM): An Emergin Multidiscipline", Knowledge Economy", keynote at 2005 IEEE International Conference on Service Operations, Logistics and Informatics(SOLI), 11 August, Beijing, China.

Stats (2006), "2005 National Statistics Bulletin For Economic And Social Development", National Bureau of Statistics of China, viewed 24 Jan 2007, [online] http://www.stats.gov.cn/tjgb/ndtjgb lqgndtjgb/t20060227 402307796.htm .

Taiyuan Statistics (2006), "2005 Statistics Bulletin For The National Economic And Social Development In Taiyuan", Taiyuan Daily, viewed 19 Dec 2006, [online] http://www.tynews.com.cn/tyrbmap/2006-03/16/content 1919779.htm .

Xi' an Information Center (2006), "2005 Statistics Bulletin For The National Economic And Social Development in Xi' an", viewed 19 Dec 2006, [online] http://www.cinic.org.cn/HTML/2006 /sxij/20062113252.html.

Xinhuanet (2003), "Provisional Regulations on Standards for SMEs", viewed 29 July 2007, [online] http://news.xinhuanet.com/zhengfu/2003-03/07/content 764043.htm .

Yu J.H. (2005). "Exploring The Development Strategy of E-commerce In SMEs". Network, viewed 3 Nov 2005, URL: http://tech.netook.com/Archives/200505/008577.asp.

Zhenjiang Government (2006), "The Zhenjiang Government Report for The National Economic And Social Development in 2005",viewed 19 Dec 2006, [online] http://www.zhenjiang.gov.cn/gb /zgzj/zjgb/zwgk/rdzt/node2790/userobject1ai7023.html. 